UDC 658.512

JEL Classification: L86, L91, M11, M15

DOI: $10.15587 / 2706-5448.2021 .248104$

Article type «Reports on Research Projects»

\title{
0leksandr Kononykhin DEVELOPMENT OF A MODEL OF SELECTING CLOUD SOFTWARE FOR A ROAD CONSTRUCTION ORGANIZATION UNDER INTERVAL INFORMATION
}

The object of research is the management processes of a road construction organization. The research is based on the principles of systems analysis for structuring design processes; methods of mathematical modeling, fuzzy mathematics, discrete programming, multicriteria assessment and optimization for the selection of cloud software for road construction organizations in terms of interval information. The information system of a road construction organization includes planning, reporting, regulatory and technical documentation that characterizes the state and movement of information in the enterprise. It is important to use systems that speed up the generation, processing and preparation of documents, as well as improve the storage and retrieval of information. The introduction of cloud technologies has become a necessary condition for increasing the mobility, flexibility and efficiency of the management system of a road construction organization. Formalized processes of information collection and internal distribution can better predict the dynamics of market trends and act more quickly, make decisions confidently and reasonably. In the final stages of selection for assessment, it is convenient to apply the criteria in conditions of interval uncertainty. The study was aimed at improving the efficiency of transport management by developing a model for choosing the cloud software of a road construction organization in terms of interval information. The following criteria of partial optimization were used in the developed model: maximum speed of execution of functions by cloud software; minimum cloud software requirements for internet connection speed; minimum cost of cloud software. The scope of permissible solutions is determined by restrictions:

- execution of all functions must be provided by cloud software;

- the minimum speed of execution of functions by the cloud software should be not lower than set;

- cloud software requirements for Internet connection speed should not exceed the specified;

- the cost of cloud software should be no more than specified.

The developed model will reduce the cost of purchasing cloud software and increase the efficiency of transport management of a road construction organization.

Keywords: road construction organization, transport management, cloud software, cloud technologies, interval information.

\section{How to cite}

Kononykhin, O. (2021). Development of a model of selecting cloud software for a road construction organization under interval information. Technology Audit and Production Reserves, 6 (4 (62)), 17-20. doi: https://doi.org/10.15587/2706-5448.2021.248104

\section{Introduction}

The functioning and efficiency of road construction enterprises directly depend on the market instruments, used to manage them. Consideration of logistics as a factor, influencing the efficiency of the enterprise, provides a way to control costs and indicators, most accurately reflects the relationship of logistics with the main economic and financial indicators of business. In this case, given the high inertia of the production system, associated with high capital intensity, long construction and reconstruction of road facilities, tasks in the field of road construction should be presented not only in the coming years, but also in the longer term [1].
The creation of a logistics system for a road construction company aims to reflect a set of organizational and technical elements that ensure inventory management and implementation of the movement of material resources in the road construction process with maximum efficiency. Within the logistics system, the functions of supply, production, sales, distribution, transportation are integrated.

Currently, the problems of the logistical approach to the organization of a road construction company are insufficiently studied. These include criteria for planning and organizing the work of the enterprise. In practice, there is an increasing need for logistical support to solve these problems. 
The research consists in the development of scientific and practical recommendations that can increase the efficiency of management and productivity of a road construction company based on the use of logistics tools. The task of the organizational structure of enterprise management is to form a relationship between employees of departments that represent the functional areas of logistics in the enterprise, and resources that will effectively achieve the goal of logistics support of the enterprise. In this regard, integration becomes relevant, a set of procedures for the enterprise, the entire system of interactions, forecasting and accounting for direct, indirect, long-term consequences of decisions in the enterprise [1].

Optimization of transport is to choose such organizational forms, functional structures that would ensure minimal costs in general from the production-transport-warehousing system. When choosing optimization criteria, priority should be given to system-wide, ie the implementation of production with minimal costs. It is the volume of production that dictates the organization and volume of transportation. Internal criteria can be considered only if the implementation of the main, which in this case will be a mandatory restriction. However, a prerequisite is the compliance of lower-order criteria with higher-level criteria, system-wide. A reliable information system is of great importance here [2].

The information system of the office of a road construction organization includes planning, reporting, regulatory and technical documentation that characterizes the state and movement of information in the enterprise. The information process provides the generation, collection, processing, use and transmission of information. These elements are the information structure of the organization.

Today it is important to use systems that speed up the generation of documents, their processing and preparation, as well as improve the storage and retrieval of information [2].

The introduction of cloud technologies has become a necessary condition for increasing the mobility, flexibility and efficiency of the management system of a road construction organization. Formalized processes for collecting information and its internal distribution can better predict the dynamics of market trends, and act more quickly, make decisions confidently and reasonably. Today, the market situation is such that most companies, regardless of the size of a company, use innovations in the development of information systems and technologies to optimize the main and auxiliary business processes [3].

Cloud information technologies provide convenient network access to a common pool of computing resources (servers, applications, networks, storage systems and services) that can be quickly provided and released with minimal management effort.

Cloud technologies are seen as new opportunities to increase the efficiency of business processes. At this level, IT infrastructure management is based on comprehensive services and policies, determined by the business requirements of the organization [3].

When using cloud computing, there is an absolute elasticity of capacity, provided for business needs and which can be used for storage, analysis and data processing. This means that the use of cloud information technology can minimize downtime of computers and equipment, as well as eliminate power shortages at high computer load [4].
There are currently three main models of cloud services:

1. Infrastructure as a Service (IaaS).

2. Platform as a Service (PaaS).

3. Software as a Service (SaaS) [4].

Let us take a closer look at the choice of SaaS software. The criteria for selecting these systems include clear and interval values, such as speed of execution of functions, requirements for the speed of the Internet connection, cost, etc.

Thus, the object of research is the management processes of a road construction organization. The purpose of the study is to increase the efficiency of transport management by developing a model for selecting cloud software for road construction organizations in terms of interval information.

\section{Methods of research}

Research methods are based on the principles of systems analysis for structuring design processes; methods of mathematical modeling, fuzzy mathematics, discrete programming, multicriteria assessment and optimization for the selection of cloud software for road construction organizations in terms of interval information [5-7].

In the final stages of selection, it is convenient to apply the criteria for estimation in the conditions of interval uncertainty, in particular, in the case under consideration, the criterion of pessimism-optimism of Hurwitz is used [8-10].

\section{Research results and discussion}

To achieve this goal it is necessary to develop a model for selecting cloud software for road construction organizations in terms of interval information.

We introduce variables:

$$
X_{\sigma \mathrm{cv}}=\{0 ; 1\},
$$

where $X_{\sigma \mathrm{cv}}=1$ - if you choose cloud software of the $c$-th type, $v$-th kind to perform the $\sigma$-th function, $X_{\sigma c v}=0$ otherwise;

$Y_{\sigma c v}=\{0 ; 1\}$

where $Y_{\sigma \mathrm{cv}}=1$ - if the $\sigma$-th function can be provided by $c v$-th cloud software, $Y_{\sigma c v}=0$ - otherwise.

Partial optimization criteria:

- the maximum speed of execution of the $\sigma$-th function by cloud software:

$$
V_{P}=\min \sum_{\sigma=1}^{\sigma^{\prime}} \sum_{c=1}^{c^{\sigma}} \sum_{v=1}^{v^{c}} V_{c v} Y_{\sigma v} X_{\sigma c v}
$$

where $V_{\sigma v}$ - interval estimation of the speed of execution of the $\sigma$-th function of cloud software, $c$-th type of $v$-th kind; - minimum cloud software requirements for Internet connection speed:

$$
R_{P}=\min \sum_{c=1}^{c^{\prime}} \sum_{v=1}^{v^{c}} R_{c v} Y_{\sigma c v} X_{\sigma c v} ; \sigma=\overline{1, \sigma^{\prime}}
$$

where $R_{c v}$ - interval estimate of the $c$-th type of $v$-kind cloud software requirements for the Internet connection; 
- the minimum cost of cloud software:

Table 1

$$
C_{P}=\min \sum_{\sigma=1}^{\sigma^{\prime}} \sum_{c=1}^{c^{\sigma}} \sum_{v=1}^{v^{c}} C_{c v} Y_{\sigma c v} X_{\sigma c v}
$$

where $C_{c v}$ - interval estimate of the cost of cloud software, $c$-th type $v$-th kind.

The scope of permissible solutions is determined by restrictions:

- execution of all functions must be provided by cloud software:

$$
\sum_{\sigma=1}^{\sigma^{\prime}} \sum_{c=1}^{c^{\sigma}} \sum_{v=1}^{v^{c}} Y_{\sigma c v} X_{\sigma c v}=\sigma^{\prime}
$$

- the minimum speed of execution of the $\sigma$-th function by cloud software should not be lower $V_{\mathrm{cv}}^{\mathrm{min}}$ :

$$
\begin{aligned}
& \sum_{\sigma=1}^{\sigma^{\prime}} V_{c v} Y_{\sigma c v} X_{\sigma c v} \geq V_{c v}^{\min } ; \\
& c=\overline{1, c^{\sigma}} ; v=\overline{1, v^{c}} ;
\end{aligned}
$$

- the requirements of the $c v$-th cloud software for the Internet connection should not exceed the specified $R^{\min }$ :

$$
\begin{aligned}
& R_{c v} Y_{\sigma c v} X_{\sigma c v} \leq R^{\min } ; \\
& c=\overline{1, c^{\sigma}} ; v=\overline{1, v^{c}} ; \sigma=\overline{1, \sigma^{\prime}} ;
\end{aligned}
$$

- the cost of cloud software should be no more than specified $C^{\min }$ :

$$
\sum_{\sigma=1}^{\sigma^{\prime}} \sum_{c=1}^{c^{\sigma}} \sum_{v=1}^{v^{c}} C_{c v} Y_{\sigma c v} X_{\sigma c v} \leq C^{\min }
$$

Model (1)-(7) refers to the problems of multicriteria discrete programming with Boolean variables, which is solved by:

- the method of directed search in decision-making in small problems;

- the random search method - in large-scale problems.

For example, consider the choice of cloud software for a road construction organization, taking into account interval estimates.

You need to choose the type of software according to the partial criteria, set by the interval (speed of execution of the function, speed of the Internet connection and cost).

The cost of the software should not exceed 211.34 USD, the speed of function execution is a little more than $0.34 \mathrm{~s}$, the speed of the Internet connection is not more than 2000 Kbps.

Table 1 shows the type of cloud software, its cost, maximum speed of function execution, the minimum speed of the Internet connection.

Since the values of the criteria are given at intervals, we will assess pessimistic and optimistic scenarios. The selection is made according to the maximum average generalized assessment. The criteria are considered equivalent.

Table 2 presents weighted interval assessments of the

\begin{tabular}{|c|c|c|c|c|c|c|c|c|}
\hline \multirow[b]{2}{*}{ Software } & \multicolumn{2}{|c|}{ Cost } & \multicolumn{2}{|c|}{$\begin{array}{l}\text { Maximum speed } \\
\text { of function } \\
\text { execution }\end{array}$} & \multicolumn{2}{|c|}{$\begin{array}{l}\text { Minimum speed } \\
\text { of Internet con- } \\
\text { nection }\end{array}$} & \multicolumn{2}{|c|}{$\begin{array}{l}\text { Generalized } \\
\text { assessment }\end{array}$} \\
\hline & $\begin{array}{c}\text { Opti- } \\
\text { mistic } \\
\text { assess- } \\
\text { ment }\end{array}$ & $\begin{array}{c}\text { Pes- } \\
\text { simistic } \\
\text { assess- } \\
\text { ment }\end{array}$ & $\begin{array}{c}\text { Opti- } \\
\text { mistic } \\
\text { assess- } \\
\text { ment }\end{array}$ & $\begin{array}{c}\text { Pes- } \\
\text { simistic } \\
\text { assess- } \\
\text { ment }\end{array}$ & $\begin{array}{c}\text { Opti- } \\
\text { mistic } \\
\text { assess- } \\
\text { ment }\end{array}$ & $\begin{array}{c}\text { Pes- } \\
\text { simistic } \\
\text { assess- } \\
\text { ment }\end{array}$ & $\begin{array}{c}\text { Opti- } \\
\text { mistic } \\
\text { assess- } \\
\text { ment }\end{array}$ & \begin{tabular}{|c|} 
Pes- \\
simistic \\
assess- \\
ment \\
\end{tabular} \\
\hline Prog1 & 0.63 & 0.37 & 1.00 & 0.44 & 1.00 & 0.76 & 0.88 & 0.52 \\
\hline Prog2 & 0.56 & 0.28 & 0.86 & 0.1 & 9 & 0.76 & 0.79 & 0.40 \\
\hline Prog3 & 0.46 & 0.18 & 1.00 & 0.30 & 0.18 & 0.00 & 0.55 & 0.16 \\
\hline Prog 4 & 0.64 & 0.38 & 0.86 & 0.30 & 0.88 & 0.59 & م7 & 0.42 \\
\hline Prog5 & 0.66 & 0.41 & 0.58 & 0.01 & 1.00 & 65 & 0.74 & 0.36 \\
\hline Prog6 & 0.66 & 0.42 & 0.72 & 0.00 & 0.88 & 0.53 & 0.75 & 0.32 \\
\hline Prog7 & 0.61 & 0.34 & 0.72 & 0.15 & 0.76 & 0.65 & 0.70 & 0.38 \\
\hline Prog8 & 1.00 & 0.00 & 0.86 & 0.30 & 1.00 & 0.82 & 0.95 & 0.37 \\
\hline 9و & 0.56 & 88 & U. & 0.30 & 0.88 & 0.41 & 0.77 & 0.33 \\
\hline Prag10 & 0.76 & 0.49 & 0.86 & 0.44 & 0.29 & 0.18 & 0.64 & 0.37 \\
\hline
\end{tabular}
cloud software assessment criteria.
Type of cloud software, its cost, maximum speed of function execution, minimum speed of Internet connection

\begin{tabular}{|c|c|c|c|c|}
\hline No. & $\begin{array}{c}\text { Type of } \\
\text { cloud } \\
\text { software }\end{array}$ & Cost, USD & $\begin{array}{c}\text { Maximum speed } \\
\text { of function } \\
\text { execution, s }\end{array}$ & $\begin{array}{c}\text { Minimum speed } \\
\text { of Internet con- } \\
\text { nection, Kbps }\end{array}$ \\
\hline 1 & Prog1 & $167.79-181.64$ & $0.27-0.31$ & $500-700$ \\
\hline 2 & Prag2 & $171.80-186.05$ & $0.28-0.33$ & $550-700$ \\
\hline 3 & Prag3 & $176.58-191.30$ & $0.27-0.32$ & $1200-1350$ \\
\hline 4 & Prag4 & $167.28-181.06$ & $0.28-0.32$ & $600-850$ \\
\hline 5 & Prag5 & $166.63-179.27$ & $0.3-0.34$ & $500-800$ \\
\hline 6 & Prog6 & $166.34-178.65$ & $0.29-0.341$ & $600-900$ \\
\hline 7 & Prag7 & $168.92-182.84$ & $0.29-0.33$ & $700-800$ \\
\hline 8 & Prag8 & $148.66-200.77$ & $0.28-0.32$ & $500-650$ \\
\hline 9 & Prag9 & $171.80-186.05$ & $0.28-0.32$ & $600-1000$ \\
\hline 10 & Prag10 & $161.05-175.48$ & $0.28-0.31$ & $1100-1200$ \\
\hline
\end{tabular}

Table 2

Weighted interval assessments of the cloud software assessment criteria

Using model (1)-(7) and Hurwitz's pessimism-optimism criterion, Prog8, which best met the criteria and constraints was chosen in the optimistic scenario, Prog1 - in the pessimistic, from the many software options.

Thus, depending on the project situation, the cost savings for the purchase of software amounted to 10-26\% relative to the maximum cost.

The study identified a number of new challenges in the field of decision support systems for road construction companies, in particular, the choice of hardware and software with assessment criteria, set by linguistic values.

\section{Conclusions}

The analysis of the process of choosing the cloud software of a road construction organization has been carried out. A model of cloud software for road construction organizations has been developed, which, in contrast to known models, allows to make design decisions, taking into account interval criteria. Using the developed model will reduce the cost 
of purchasing cloud software and increase the efficiency of transport management of a road construction organization.

\section{References}

1. Nefodov, L. I., Petrenko, Yu. A., Plugina, T. V. et al. (2010) Modeli $i$ metody sinteza ofisov po upravleniyu programmami $i$ proyektami. Kharkiv: KHNADU, 344.

2. Erl, T., Puttini, R., Mahmood, Z. (2013). Cloud Computing: Concepts, Technology \& Architecture. Pearson, 528.

3. Rhoton, J. (2009). Cloud Computing Explained: Implementation Handbook for Enterprises. 2nd ed. Recursive Press, 509.

4. Kavis, M. J. (2014). Architecting the Cloud: Design Decision for Cloud Computing Service Models (SAAS, PAAS and IAAS). Wiley, 224.

5. Sigal, I. Kh., Ivanova, A. P. (2003). Vvedeniye v prikladnoye diskretnoye programmirovaniye: modeli i vychislitel'nyye algoritmy. Moscow: Fizmatlit, 238.
6. Norenkov, I. P. (2002). Avtomatizirovannoye proyektirovaniye. Moscow: MGTU im. N. E. Baumana, 336.

7. Kryuchkovskiy, V. V., Petrov, E. G., Sokolova, N. A., Khodakov, V. Ye. (2013). Vvedeniye v normativnuyu teoriyu prinyatiya resheniy. Metody i modeli. Kherson: Grin’ D.S., 284

8. Ovezgel'dyyev, A. O., Petrov, E. G., Petrov, K. E. (2002). Sintez i identifikatsiya modeley mnogofaktornogo otsenivaniya $i$ optimizatsii. Kyiv: Naukova dumka, 164.

9. Bellman, R. E., Zadeh, L. A. (1970). Decision-Making in a Fuzzy Environment. Management Science, 17 (4), B-141-B-164. doi: https://doi.org/10.1287/mnsc.17.4.b141

10. Petrov, E. H., Novozhylova, M. V., Hrebennik, Sh. V. (2002) Metody $i$ zasoby pryiniattia rishen u sotsialno-ekonomichnykh systemakh. Kharkiv: KhDTUBA, 284.

Oleksandr Kononykhin, PhD, Associate Professor, Department of Automation and Computer-Aided Technologies, Kharkiv National Automobile and Highway University», Kharkiv, Ukraine, e-mail: makonon@i.ua, ORCID: https://orcid.org/0000-0002-6396-6836 